\title{
Seasonal variation of energy reserves and reproduction in neotropical free-tailed bats Molossus molossus (Chiroptera: Molossidae)
}

\author{
Barros, MS. ${ }^{a *}$, Morais, DB. ${ }^{b}$, Araújo, MR. ${ }^{b}$, Carvalho, $T F{ }^{a}$, Matta, SLP. ${ }^{b}$, Pinheiro, EC ${ }^{c}$ \\ and Freitas, $M B .^{a}$ \\ ${ }^{a}$ Ecophysiology Laboratory, Department of Animal Biology, Federal University of Viçosa, CEP 36570-000, \\ Viçosa, MG, Brazil \\ ${ }^{b}$ Structural and Reproductive Biology Laboratory, Department of General Biology, Federal University of Viçosa, \\ Viçosa, Av. PH Rolfs s/n, Campus UFV, CEP 36570-000, Viçosa, MG, Brazil \\ ${ }^{c}$ Department of Physiological Sciences, Institute of Biological Sciences, University of Brasilia, Campus Darcy Ribeiro, \\ CEP 70910-900, Brasília, DF, Brazil \\ *e-mail: enialrim@hotmail.com
}

Received March 20, 2012 - Accepted August 30, 2012 - Distributed August 31, 2013

(With 3 figures)

\begin{abstract}
Seasonal variation is a key factor regulating energy metabolism and reproduction in several mammals, including bats. This study aimed to track seasonal changes in the energy reserves of the insectivorous bat Molossus molossus associated with its reproductive cycle. Adult males were collected during the four neotropical annual seasons in Viçosa - MG, Brazil. Blood and tissues were collected for metabolic analysis and testes were removed for histology and morphometry. Our results show that liver and breast muscle glycogen concentrations were significantly lower in winter. The adiposity index was significantly higher in the fall compared to winter and spring. Seminiferous tubules were greater in diameter in animals captured in fall and winter, indicating a higher investment in spermatic production during these seasons. The percentage of Leydig cells was higher in summer compared to fall and winter. We suggest that $M$. molossus presents a type of seasonal reproduction with two peaks of testicular activity: one in fall, with higher sperm production (spermatogenesis), and another in summer, with higher hormone production (steroidogenesis). The metabolic pattern may be associated with reproductive events, especially due to the highest fat storage observed in the fall, which coincides with the further development of the seminiferous tubules.
\end{abstract}

Keywords: spermatogenesis, histology, insectivorous, males, metabolism.

\section{Variação sazonal das reservas energéticas e a reprodução do morcego neotropical de cauda livre Molossus molossus (Chiroptera: Molossidae)}

\section{Resumo}

A variação sazonal é um fator chave na regulação do metabolismo energético e da reprodução em vários mamíferos, incluindo os morcegos. O objetivo deste estudo foi avaliar as reservas energéticas do morcego insetívoro Molossus molossus ao longo das estações anuais associadas ao seu ciclo reprodutivo. Foram coletados machos adultos durante as quatro estações anuais na cidade de Viçosa - MG, Brasil. Para as análises metabólicas foram coletados tecidos e sangue, e os testículos foram removidos para análises histológicas e morfométricas. Os resultados mostram que as concentrações de glicogênio no fígado e músculo peitoral foram significativamente menores no inverno. O índice adiposo foi significativamente maior no outono em relação ao inverno e primavera. Os túbulos seminíferos apresentaram maiores diâmetros nos animais coletados no outono e inverno, indicando um maior investimento na produção espermática durante estas estações. A porcentagem de células de Leydig foi maior no verão em comparação com outono e inverno. Sugere-se que M. molossus apresenta um tipo de reprodução sazonal com dois picos de atividade testicular: uma no outono, com maior produção de espermatozóides (espermatogênese), e outra no verão, com maior produção de hormônio (esteroidogênese). O padrão metabólico pode estar associado a eventos reprodutivos, especialmente devido ao maior armazenamento de gordura observado no outono, que coincide com o desenvolvimento dos túbulos seminíferos.

Palavras-chave: espermatogênese, histologia, insetívoros, machos, metabolismo. 


\section{Introduction}

Seasonal variation is a key factor regulating energy metabolism and reproduction in several mammals, including bats (Arévalo et al., 1990; Bauman, 1990; Happold and Happold, 1990; Neuwriler, 2000). According to Srivastava and Krishna (2008), this is especially significant for bats from temperate regions, since their reproduction is frequently synchronized with food availability in the environment. For neotropical bats, the influence of seasonality on energy reserve allocation and reproductive events appears to vary between species, depending on their food habits and area of occurrence (Altringham, 1998; Neuwriler, 2000; Freitas et al., 2006).

Microchiropterans show a great diversity in food habits, with frugivorous, insectivorous, piscivorous, pollinivorous, nectarivorous, carnivorous, omnivorous and hematophagous species (Nowak, 1994). Several studies have shown that the diet composition interferes directly with the metabolic pattern displayed by diverse vertebrates (Nagy and Pistole, 1988; Silva and Migliorini, 1990; Sartori et al., 1995), including bats (Freitas et al., 2003; Pinheiro et al., 2006; Freitas et al., 2010; Protzek et al., 2010). Another factor which also interferes with energy metabolism is the species' reproductive patterns, which are directly linked to environmental conditions and food availability (Pirlot, 1967; Dweyr, 1970; Wojciechowski et al., 2007).

The insectivorous bat Molossus molossus consumes a high amount of protein and acts as controller of insect populations preying large amounts each night in the first hours of the night (Esbérard and Bergallo, 2010), playing an important role in the ecological balance. This species has a reproductive cycle defined as seasonal polyestrous by Fabian and Marques (1989) in northeastern Brazil, and as seasonal monoestral by Pacheco (2001) in the southern region of the country. The reproductive behaviour of M. molossus seems to be similar to other insectivorous bats, which have a typically monoestral reproductive pattern, but when food availability are not subject to seasonal variations, they can reproduce poliestrically, with peak birth twice a year (Fleming et al., 1972; LaVal and Fitch, 1977).

This study aimed to track changes in energy reserves of the insectivorous bat $M$. molossus associated with the reproductive cycle of these animals. For this purpose, we investigated seasonal variations of glycogen, fat and muscle concentrations in liver, fat and muscle throughout the year, and also several reproductive parameters during the same period.

\section{Material and Methods}

\subsection{Animals}

M. molossus adult males $(\mathrm{n}=18)$ weighing $15-20 \mathrm{~g}$ were collected during the four neotropical annual seasons: summer (January and March, $n=5$ ), fall (April and June, $n=5$ ), winter (July and August, $n=4$ ) and spring (October, $n=4$ ). The identification of adult bats was done based on the fusion zone region of the cartilaginous epiphysis of the fourth metacarpal-phalangeal joint (Kunz and Anthony, 1982). The animals were captured in Viçosa, southeastern of Minas Gerais, Brazil (2045'4" S and $42^{\circ} 52^{\prime} 53^{\prime \prime} \mathrm{W}$ ). The region has a climate Cwa (mesothermal, humid, rainy summers and dry winters with low rainfall). Animals were captured in refuges roofs through mist nets and kept in cages in the laboratory of Ecophysiology of the Federal University of Viçosa (UFV), Viçosa, Minas Gerais State, Brazil, until the next day when they were euthanized. During captivity, the animals were force-fed Tenebrio molitor larvae at 22:00 h, 00:00 h and 07:00 h, and had water ad libitum.

All captures were authorized by the IBAMA (Brazilian Institute of Environment and Natural Resources) (process number 11388-1) and all experimental procedures were approved by the Ethics Committee for Animal Experimentation of Federal University of Viçosa (case number 88831/2009).

\subsection{Experimental procedures}

\subsubsection{Metabolic analysis}

Bats were killed by decapitation. For plasma glucose analysis, blood was collected in heparinized tubes, centrifuged ( $\mathrm{g}=268)$ and plasma was assayed by the glucose oxidase method (GLUCOX 500 kit, Doles). For total protein determination, portions of breast muscle and liver were homogenized in saline $(\mathrm{NaCl} 0.9 \%)$ and protein was determined by a colorimetric method (BCA kit, PIERCE). For analysis of carcass total fatty acids, carcasses were digested in $200 \mathrm{~mL}$ of $6 \mathrm{~N} \mathrm{KOH}$ for 1 week, filtered and added to an equal volume of absolute alcohol, resulting in a solution of KOH-ethanol $(50 \% \mathrm{v} / \mathrm{v})$. A sample of this solution was washed with petroleum ether, acidified, and subjected to lipid extraction with chloroform. A known volume of this phase was used for the determination of total fatty acids by a gravimetric method. For total lipid determination, liver, breast and limb muscles were homogenized in a chloroform-methanol solution (2:1) according to Folch et al. (1957). After extraction, total lipid concentrations were determined gravimetrically. Adiposity index was obtained by dividing the adipose tissue weight (abdominal and subaxilar areas) (g) by the individual body weight $(\mathrm{g})$.

\subsubsection{Testicular histology and morphometry}

The testes were removed, weighed, and fixed in Karnovsky solution for $24 \mathrm{~h}$. Testicular fragments were dehydrated in increasing concentrations of ethanol followed by inclusion in glycol-methacrylate (Historesin ${ }^{\circledR}$ Leica). We obtained $3 \mu \mathrm{m}$ thick semi-serial sections, with $40 \mu \mathrm{m}$ intervals between two successive cuts, thus avoiding analyzing the same seminiferous tubule. Preparations were stained with toluidine blue/sodium borate $1 \%$, mounted with Entellan ${ }^{\circledR}$ (Merck), and analyzed under a light microscope (Balarini et al., 2011). The gonadosomatic index (GSI) was obtained to determine the percentage of body weight occupied by both testes by the 
formula: $\mathrm{GSI}=\mathrm{TW} / \mathrm{BW} \times 100$, where $\mathrm{TW}=$ total weight of the gonads, and BW = body weight.

The volumetric proportion between tubular and intertubular compartments was randomly counted at 2,660 points per animal, using a grid with 266 intersections (points) at 100x magnification, by counting 10 randomly distributed fields in different histological sections of each animal testis. The percentage of each element in the intertubular compartment was obtained by counting 1,000 points for each animal, registering points on Leydig cells, blood and lymphatic vessels, and connective tissue. The mean tubular diameter per animal was obtained from random measurements from 20 crosssections of seminiferous tubules. In these same sections was obtained the height of the seminiferous epithelium, from the tunica propria to the tubular lumen. The value found for the epithelium height, in each tubule, represented the average of two measurements obtained in a diametrical opposite angle.

Based on the volume of seminiferous tubules and on the body weight, we calculated the tubulesomatic index (TSI) from the formula: TSI $=$ VST $/$ BW $\times 100$, where $\mathrm{VST}=$ volume of seminiferous tubules and $\mathrm{BW}=$ body weight. The VST $(\mathrm{mL})$ was estimated from the percentage occupied by the seminiferous tubules in the testis and the testicular parenchyma volume. These data were obtained by subtracting the total testicular weight of the total weight of the testicular albuginea. As the density of the testicle is around 1 (Johnson et al., 1981; Costa et al., 2011), the testis weight was considered equal to its volume. These measures were performed using the software Image-Pro Plus ${ }^{\circledR}$ associated to photomicroscope Olympus $\mathrm{AX}-70$, in a $200 \mathrm{x}$ magnification.

\subsubsection{Statistical analysis}

Data are presented as mean \pm standard error of the mean (SEM). For metabolic and histological parameters, we checked for the variables normality (Lilliefors) and homoscedasticity (Cochran). After that, we performed analysis of variance (ANOVA) followed by the Tukey test at a significance level of $0.05 \%(\mathrm{p}>0.05)$.

\section{Results}

\subsection{Seasonal variation of energy reserves}

Table 1 shows significant and non-significant $\mathrm{p}$ values in metabolic parameters among seasons. Liver glycogen concentrations were significantly lower in winter compared to summer (Figure 1, Table 1). Breast muscle glycogen concentration showed significantly lower values for animals captured during the winter compared to those captured in all other seasons (Figure 1 , Table 1).

Total lipid concentrations in liver, breast muscle, forelimbs and hindlimbs showed no significant differences among seasons. Carcass total fatty acid content also remained unaltered across seasons (Table 2). Considering the adiposity index, animals captured during

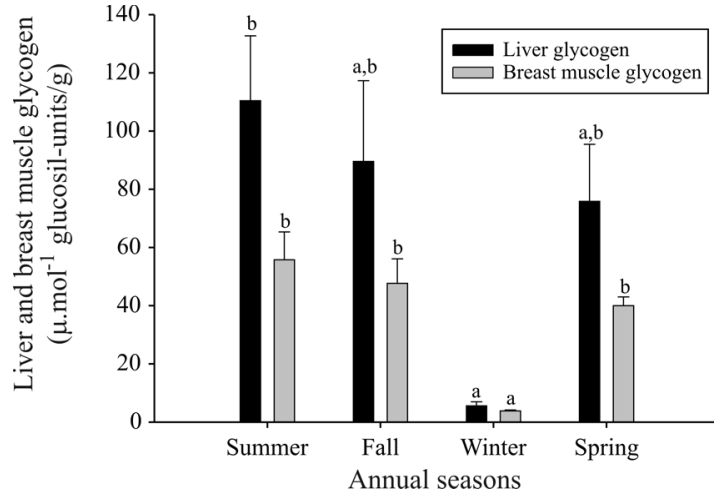

Figure 1 - Concentrations of glycogen in liver and breast muscle of M. molossus males collected during the annual seasons.

Table 1 - Statistical summaries: One Way-ANOVA of metabolic parameters from male adults $M$. molossus collected in different annual seasons. $\mathrm{DF}=$ degree of freedom; $\mathrm{F}=\mathrm{F}$ values; $\mathrm{P}=\mathrm{p}$ values

\begin{tabular}{lccc}
\hline Parameters & DF & F & P \\
\hline Plasma glucose & 3.14 & 1.86 & 0.18 \\
Liver glycogen & 3.14 & 4.14 & 0.03 \\
Breast muscle glycogen & 3.14 & 9.35 & 0.001 \\
Liver lipids & 3.14 & 1.16 & 0.36 \\
Breast muscle lipids & 3.14 & 3.12 & 0.06 \\
Forelimbs and hindlimbs lipids & 3.14 & 1.40 & 0.28 \\
Adiposity index & 3.14 & 4.35 & 0.02 \\
Carcass total fatty acids & 3.14 & 0.02 & 0.10 \\
\hline
\end{tabular}

fall had a significantly higher value compared to animals caught during winter and spring (Figure 2, Table 1).

\subsection{Testicular histomorphometry}

In Table 3 it is possible to observe the mean values for the biometrical data and for the testicular morpho-

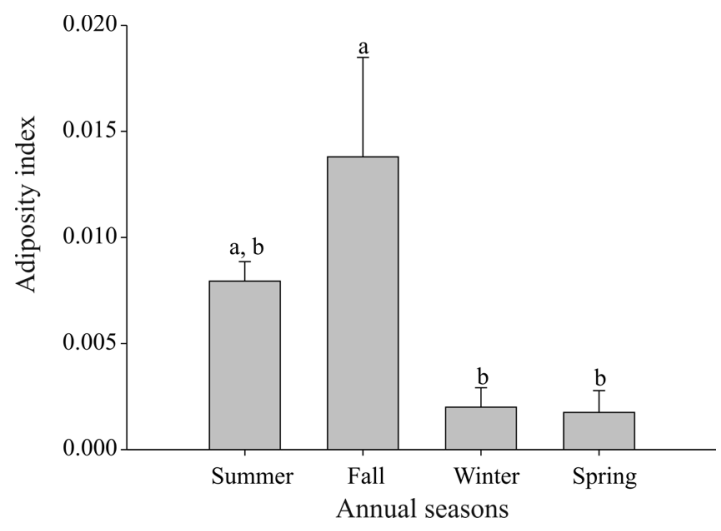

Figure 2 - Index of adipose of $M$. molossus males collected during the annual seasons. 
Barros, MS. et al.

Table 2 - Plasma glucose concentration, liver and breast muscle lipid contents, forelimbs and hindlimbs lipid contents and carcass total fatty acids from male adults $M$. molossus collected along different annual seasons.

\begin{tabular}{lcccc}
\hline Parameters & Summer $(\mathbf{N}=\mathbf{5})$ & Fall $(\mathbf{N}=\mathbf{5})$ & Winter $(\mathbf{N}=\mathbf{4})$ & Spring $(\mathbf{N}=\mathbf{4})$ \\
\hline Plasma Glucose $\left(\mathrm{mmol}^{-1}\right)$ & $8.38 \pm 0.63$ & $7.52 \pm 0.74$ & $5.55 \pm 0.91$ & $7.45 \pm 1.2$ \\
Liver lipids $\left(\mathrm{g} .100 \mathrm{~g} \mathrm{~g}^{-1}\right)$ & $7.06 \pm 0.61$ & $6.04 \pm 1.39$ & $8.75 \pm 1.29$ & $7.71 \pm 0.52$ \\
Breast muscle lipids $\left(\mathrm{g} .100 \mathrm{~g}^{-1}\right)$ & $11.64 \pm 0.33$ & $9.80 \pm 0.67$ & $9.70 \pm 0.95$ & $8.61 \pm 0.94$ \\
Forelimbs and hindlimbs lipids $\left(\mathrm{g} .100 \mathrm{~g}^{-1}\right)$ & $8.07 \pm 0.93$ & $8.33 \pm 0.75$ & $6.29 \pm 1.85$ & $5.68 \pm 0.69$ \\
Carcass total fatty acids $\left(\mathrm{g} .100 \mathrm{~g}^{-1}\right)$ & $6.27 \pm 0.55$ & $6.17 \pm 0.71$ & $6.02 \pm 1.27$ & $6.01 \pm 0.71$ \\
\hline
\end{tabular}

Data are mean \pm SEM. The number of bats is given in parenthesis.

metry, likewise the percentage represented by the tubular and intertubular compartments and their components during the seasons. Body weight was significantly higher in summer compared to fall and winter, while the testicular weight showed an increase in fall and winter compared to summer, leading to a lower GSI in summer compared to all other seasons. The percentage of the testes occupied by seminiferous tubules was higher in fall and winter compared to summer. As a consequence, the percentage of the intertubular compartment was higher in summer than in fall and winter, and was unaltered during spring (Figure 3).

We found that percentage of tubular compartment occupied by lumen showed large variations and was significantly higher in fall and winter compared to summer. The percentage of seminiferous epithelium did not chan-

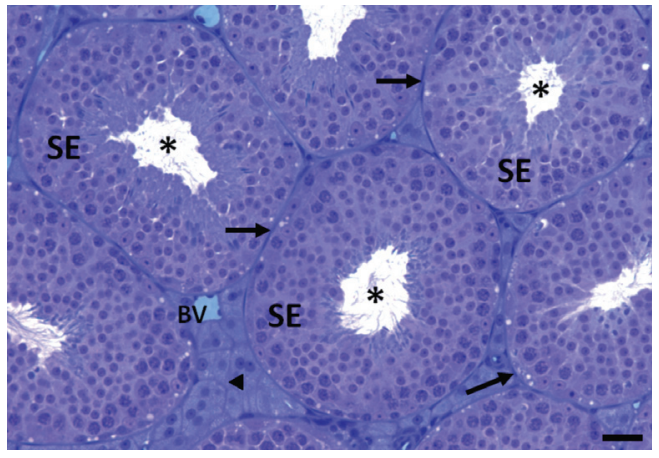

Figure 3 - Cross section of M. molossus testis captured during the fall. *: lumen of the seminiferous tubule; SE: seminiferous epithelium; $\rightarrow$ : tunica propria; $\rightarrow$ : Leydig cells in the intertubular compartment; BV: blood vessel. Bar: $40 \mu \mathrm{m}$.

Table 3 - Biometrical data and morphometrical parameters of the tubular and intertubular compartments in the testes of adults M. molossus collected along different annual seasons.

\begin{tabular}{lcccc}
\hline Parameters & Summer & Fall & Winter & Spring \\
\hline Body weight $(g)$ & $17.46 \pm 2.11^{\mathrm{a}}$ & $14.97 \pm 1.46^{\mathrm{b}}$ & $15.31 \pm 1.64^{\mathrm{b}}$ & $14.271 .58^{\mathrm{ab}}$ \\
Testicular weight $(\mathrm{g})$ & $0.057 \pm 0.018^{\mathrm{b}}$ & $0.084 \pm 0.008^{\mathrm{a}}$ & $0.077 \pm 0.013^{\mathrm{a}}$ & $0.068 \pm 0.023^{\mathrm{ab}}$ \\
Gonadosomatic index (\%) & $0.33 \pm 0.11^{\mathrm{b}}$ & $0.56 \pm 0.08^{\mathrm{a}}$ & $0.50 \pm 0.04^{\mathrm{a}}$ & $0.47 \pm 0.12^{\mathrm{a}}$ \\
Seminiferous tubules (\%) & $85.54 \pm 3.36^{\mathrm{b}}$ & $90.49 \pm 2.80^{\mathrm{a}}$ & $92.38 \pm 4.07^{\mathrm{a}}$ & $88.84 \pm 3.67^{\mathrm{ab}}$ \\
Lumen (\%) & $6.73 \pm 1.86^{\mathrm{b}}$ & $11.89 \pm 2.94^{\mathrm{a}}$ & $12.85 \pm 2.74^{\mathrm{a}}$ & $9.49 \pm 2.16^{\mathrm{ab}}$ \\
Seminiferous epithelium (\%) & $77.30 \pm 4.48^{\mathrm{a}}$ & $75.25 \pm 3.77^{\mathrm{a}}$ & $76.31 \pm 6.95^{\mathrm{a}}$ & $75.89 \pm 1.73^{\mathrm{a}}$ \\
Tunica propria (\%) & $1.51 \pm 1.06^{\mathrm{b}}$ & $3.35 \pm 0.32^{\mathrm{a}}$ & $3.22 \pm 0.36^{\mathrm{a}}$ & $3.46 \pm 1.24^{\mathrm{a}}$ \\
Tubular diameter $(\mu \mathrm{m})$ & $133.23 \pm 14.16^{\mathrm{c}}$ & $160.87 \pm 6.28^{\mathrm{a}}$ & $155.44 \pm 8.74^{\mathrm{ab}}$ & $139.50 \pm 19.88^{\mathrm{bc}}$ \\
Epithelium height $(\mu \mathrm{m})$ & $53.57 \pm 5.05^{\mathrm{a}}$ & $57.97 \pm 5.58^{\mathrm{a}}$ & $55.35 \pm 1.61^{\mathrm{a}}$ & $50.54 \pm 6.68^{\mathrm{a}}$ \\
Tubulesomatic index $(\%)$ & $0.25 \pm 0.08^{\mathrm{b}}$ & $0.46 \pm 0.07^{\mathrm{a}}$ & $0.42 \pm 0.04^{\mathrm{a}}$ & $0.37 \pm 0.11^{\mathrm{a}}$ \\
Intertubule $(\%)$ & $14.46 \pm 3.36^{\mathrm{a}}$ & $9.51 \pm 2.80^{\mathrm{b}}$ & $7.62 \pm 4.07^{\mathrm{b}}$ & $11.16 \pm 3.67^{\mathrm{ab}}$ \\
Leydig cells $(\%)$ & $12.55 \pm 2.68^{\mathrm{a}}$ & $8.24 \pm 2.63^{\mathrm{b}}$ & $6.63 \pm 3.55^{\mathrm{b}}$ & $9.85 \pm 3.44^{\mathrm{ab}}$ \\
Blood vessels $(\%)$ & $0.93 \pm 0.65^{\mathrm{a}}$ & $0.73 \pm 0.21^{\mathrm{a}}$ & $0.62 \pm 0.29^{\mathrm{a}}$ & $0.67 \pm 0.29^{\mathrm{a}}$ \\
Lymphatic space $(\%)$ & $0.40 \pm 0.38^{\mathrm{a}}$ & $0.23 \pm 0.18^{\mathrm{a}}$ & $0.05 \pm 0.04^{\mathrm{a}}$ & $0.08 \pm 0.08^{\mathrm{a}}$ \\
Connective tissue $(\%)$ & $0.57 \pm 0.31^{\mathrm{a}}$ & $0.31 \pm 0.18^{\mathrm{a}}$ & $0.33 \pm 0.28^{\mathrm{a}}$ & $0.55 \pm 0.27^{\mathrm{a}}$ \\
\hline
\end{tabular}

Data are mean \pm SEM. Identical letters in columns represent no significant differences $(p<0.05)$. 
ge significantly across seasons, while the percentage of tunica was lower in summer compared to other seasons. The tubular diameter was higher in fall and winter compared to summer, while the height of the seminiferous epithelium did not vary significantly among the seasons. Similar to the GSI, the TSI was lower in summer compared to all other seasons.

In relation to the intertubular compartment, the percentage of Leydig cells was higher in summer than in fall and winter, showing no significant variation in spring. This cell was the most abundant element in the intertubule. The percentage of the testes occupied by blood and lymphatic vessels and connective tissue remained unaltered in animals captured in all seasons.

\section{Discussion}

The neotropical insect-eating bat M. molossus studied here showed slight variations in energy reserves and reproductive activities throughout the annual seasons, suggesting that this species can maintain standard reserves and sperm production without major changes imposed by different seasons. The maintenance of normal blood glucose concentrations across seasons seems to confirm this hypothesis.

Flying vertebrates, such as bats, face exceptionally high energy costs during flight (Voigt et al., 2010). It has been reported that insect-eating bats are able of fly while foraging powered by exogenous (dietary nutrients) rather than endogenous sources (glycogen or lipids) (Voigt et al., 2010). Reproductive activity in insect-eating bats also seems to require great energy expenditure, but this is based mainly on body lipid reserves stored during the previous seasons (Kunz et al., 1998; Krishna et al., 1998; Srivastava and Krishna, 2007; 2008).

Among the few changes observed in the metabolic parameters, we found a decrease in glycogen concentration in liver and breast muscle during the winter, suggesting mobilization of this reserve in this period. Glycogen reserves in muscles contribute mainly to the energy requirements of the muscle itself (Maughan, 2005), although this substrate also contributes notably to energy homeostasis by providing lactate for glucose synthesis via gluconeogenesis (Tappy, 1995; 2004; Corssmit et al., 2001). Another possible reason for the glycogen decrease could be a reduction in food availability in the environment during this season, which is pronounced in temperate insectivorous species (Turbill et al., 2003). One cannot discard that an increment in energy expenditure in the previous season (fall) due to a greater reproductive investment (spermatogenesis), indicated by the increase in the diameter of seminiferous tubules could yet contribute to the glycogen depletion observed here.

Although glycogen has an important role in energy homeostasis, several bat species rely mainly on lipid reserves to support reproductive activities (Kunz et al., 1998; Krishna et al., 1998; Srivastava and Krishna, 2007; 2008). The data obtained here seem to indicate that lipid reserves of male $M$. molossus remained unaltered in all seasons, except for the adiposity index. Common vampire bats (Desmodus rotundus) captured in central Brazilian areas also showed no significant differences in lipid reserves between dry and rainy seasons (Freitas et al., 2006). Nevertheless, unlike the observed for insectivorous species (Srivastava and Krishna, 2008), the vampire's food supply (bovine blood) does not vary seasonally. Temperate species, which have been the focus of most studies, show a different pattern of energy storage, with several hibernating species, compared to the nonhibernating neotropicals (McNab, 1976; Arévalo et al., 1990; Bauman, 1990; Kunz et al., 1998; Speakman and Rowland, 1999).

Considering the adiposity index, M. molossus was found to have a higher proportion in fall compared to the two subsequent seasons (winter and spring). The highest fat weight per body weight found in fall might be a result of the greater availability of food during the previous season, summer, resulting in greater energy storage to be used in the subsequent season, when a reduction in food availability is expected (Srivastava and Krishna, 2008). The synthesis of energy reserves is essential to meet energy demand during critical periods (Arévalo et al., 1990). Lipids stored in adipose tissue as triglycerides are the main fuel that can be widely stocked as energy reserves to support food shortage (Gleeson, 2005), and is essential to animals for reproductive investment, an event that requires large energy demands (Kunz et al., 1998; Srivastava and Krishna, 2008).

In view of lipid store mobilization for reproductive purposes, the higher adiposity index during the fall might support events such as spermatogenesis, as suggested by the higher percentage of tubular diameter during fall and winter compared to the other seasons, whereas the lumen percentage was higher in fall, winter and spring, which was accompanied to the percentage of tunica propria. According to França and Russell (1998), the increase in lumen is directly responsible for an increase in tubular diameter. The increase in tubular diameter, in turn, is directly related to an increase in spermatogenic activity.

During fall and winter we also observed higher testicular weight and a higher percentage of seminiferous tubules compared to summer. The increased investment in testicular mass and adipose tissue during fall can be associated with higher sperm production, mating and fertilization occurring in late fall and early winter. Thus, we suggest that most female bats might get pregnant around this period. Considering that pregnancy lasts about 90 days (Vicente et al., 2006), pups would be born starting in early spring, a season with greater food availability and more favorable temperatures for offspring development. This hypothesis is supported by the increase in the tubulesomatic index, gonadosomatic index and testicular weight in the fall, compared to the lower values found in the previous season (summer). While the gonadosomatic index represents the percentage of body mass that corresponds to the testis, the tubulesomatic index is a parameter used to quantify the investment in seminiferous tubules in relation to body mass (Balarini et al., 2011). 
The increase in the percentage of Leydig cells observed in male bats captured during the summer seems to have contributed to the increased size of the intertubular compartment observed in this season. Leydig cells provide all androgens necessary to support spermatogenesis (O'Donnell et al., 2001; Gilbert, 2006), and is the predominant element in the intertubular compartment of $\mathrm{M}$. molossus. In this way, the observed increase in percentage of Leydig cells is possibly an indication of an increase in steroidogenesis in M. molossus during summer, in preparation for the mating season, starting in the fall. This suggestion is corroborated by the increase in several tubular morphometric parameters in the fall.

Data obtained in this study suggest that males from this species presents a seasonal reproduction with two peaks of testicular activity: one in fall, with higher sperm production (spermatogenesis), and another in summer, with higher hormone production (steroidogenesis). We also suggest that the metabolic pattern may be associated with these reproductive events. The greatest amount of adipose tissue observed in the fall also coincides with further development of the seminiferous tubules, suggesting that this reserve has an important role in supplying higher energy demands during reproductive activities.

\section{Acknowledgments}

This study was supported by FAPEMIG - Research Support Foundation of Minas Gerais State, Brazil and CAPES (Grant to D.B. Morais).

\section{References}

ALTRINGHAM, JD., 1998. Bats: Biology and behavior. New York: Oxford University Press.

ARÉVALO, F., BURGOS, MJ., DEL HOYO, N., LÒPEZLUNA, P., 1990. Seasonal variations in the lipid composition of white and brown tissues in the bat Pipistrellus pipistrellus. Comparative Biochemistry and Physiology Part B: Comparative Biochemistry, vol. 95, p. 535-539.

BALARINI, MK., PAULA, TAR., MATTA, SLP., PEIXOTO, JV., GUIÃO-LEITE, FL., ROSSI JUNIOR, JL., CZERMAK JUNIOR, AC., WALKER, NJ., 2011. Stages and duration of the cycle of the seminiferous epithelium in oncilla (Leopardus tigrinus, Schreber, 1775). Theriogenology, vol. 77, no. 5, p.873-880.

BAUMAN, WA., 1990. Seasonal changes in pancreatic insulin and glucagon in the little brown bat (Myotis lucifugus). Pancreas, vol. 5, p.342-346.

CORSSMIT, EP., ROMIJN, JA., SAUERWEIN, HP., 2001. Regulation of glucose production with special attention to nonclassical regulatory mechanisms: a review. Metabolism, vol. 50, p. 742-755.

COSTA, KLC., MATTA, SLP., GOMES, MLM., PAULA, TAR., FREITAS, KM., CARVALHO, FAR., SILVEIRA, JA., DOLDER, H., MENDIS-HANDAGAMA, SLMC., 2011. Histomorphometric evaluation of the neotropical brown brocket deer Mazama gouazoubira testis, with an emphasis on cell population indexes of spermatogenic yield. Animal Reproduction Science, vol. 127, no. 34, p. 202-212.
DWEYR, PD., 1970. Latitude and breeding season in a polyestrus species of Myotis. Journal of Mammalogy, vol. 51, no. 2, p. 405-410.

ESBÉRARD, CEL., BERGALLO, HC., 2010. Foraging activity of the free-tailed bat Molossus molossus (Chiroptera; Molossidae) in southeastern Brazil. Brazilian Journal of Biology, vol. 70, no. 4, p. 1011-1014.

FABIAN, ME., MARQUES, RV., 1989. Contribuição ao conhecimento da biologia reprodutiva de Molossus molossus (Pallas, 1766) (Chiroptera, Molossidae). Revista Brasileira de Zoologia, vol. 6, no. 4, p. 603-610.

FLEMING, TH., HOOPER, ET., WILSON, DE., 1972. Three Central American bat communities: structure, reproductive cycles and movement patterns. Ecology, vol. 53, p. $555-569$.

FOLCH, J., LESS, M., SLORNE STANLEY, GH., 1957. A simple method for the isolation and purification of total lipids from animal tissues. Journal of Biological Chemistry, vol. 226, p. 497-509.

FRANCCA, LR., RUSSELL, LD., 1998. The testis of domestic mammals. In: MARTINEZ-GARCIA, F., REGADERA, J. (Eds.), Male reproduction: a multidisciplinary overview. Madrid: Churchill Livingstone. p. 197-219.

FREITAS, MB., WELKER, AF., MILLAN, SF., PINHEIRO, EC., 2003. Metabolic responses induced by fasting in the common vampire bat (Desmodus rotundus). Journal of Comparative Physiology B, vol. 173, no. 8, p. 703-707.

FREITAS, MB., WELKER, AF., PINHEIRO, EC., 2006. Seasonal Variation and food deprivation in common vampire bats (Chiroptera: Phyllostomidae). Brazilian Journal of Biology, vol. 66, no. 4, p. 1051-1055.

FREITAS, MB., GOULART, LS., BARROS, MS., MORAIS, DB., AMARAL, TS., MATTA, SLP., 2010. Energy metabolism and fasting in male and female insectivorous bats Molossus molossus (Chiroptera: Molossidae). Brazilian Journal of Biology, vol. 70, no. 3, p.617-621.

GILBERT, SF., 2006. Developmental Biology. Sunderland, Massachusetts: Sinauer Associates.

GLEESON, M., 2005. Basic metabolism I: Fat. Surgery (Oxford), vol. 23, p. 83-88.

HAPPOLD, DCD., HAPPOLD, M., 1990. Reproductive strategies of bats in Africa. Journal of Zoology, no. 222, p. 557-583.

JOHNSON, L., PETTY, CS., NEAVES, WB., 1981. A new approach to quantification of spermatogenesis and its application to germinal cell attrition during human spermatogenesis. Biology of Reproduction, vol. 25, p. 217-226.

KRISHNA, A., SINGH, K., DOVAL, J., CHANDA, D., 1998. Changes in circulating insulin and corticosterone concentrations during different reproductive phases and their relationships to body weight and androstenedione concentration of male Scotophilus heathi. Journal of Experimental Zoology, vol. 281, p. 201-206.

KUNZ, TH., ANTHONY, ELP., 1982. Age estimation and post-natal growth in the bat Myotis lucifugus. Journal of Mammalogy, vol. 63, p. 23-32.

KUNZ, TH.,WRAZEN, JA., BURNETT, CD., 1998. Changes in body mass and fat reserves in pré-hibernating little brown bats (Myotis lucifugus). Ecoscience, vol. 5, p. 8-17.

LaVAL, RK., FITCH, HS., 1977. Structure, movement and reproduction in three Costa Rica bat communities. Occasional Papers of the Museum of Natural History (The University of Kansas), vol. 69, p. 1-27.

MAUGHAN, R., 2005. Basic metabolism II: carbohydrate. Surgery (Oxford), vol. 23, p. 154-158. 
MCNAB, B., 1976. Seasonal fat reserves of bats in two tropical environments. Ecology, vol. 57, p. 332-338.

NAGY, TR., PISTOLE, DH., 1988. The effects of fasting on some physiological parameters in the meadow vole Microtus pennylvanicus. Comparative Biochemistry and Physiology Part A: Physiology, vol. 91, p. 679-684.

NEUWEILER, G., 2000. The biology of bats. New York: Oxford University Press.

NOWAK, R. M., 1994. Walker's Bats of the world. London: Johns Hopkins University Press.

O’DONNEL, L., ROBERTSON, KM., JONES, ME., 2001. Estrogen and spermatogenesis. Endocrinology, vol. 22, p. 280-318.

PACHECO, SM., 2001. Biologia reprodutiva, desenvolvimento pré e pós-natal e maturidade sexual de morcegos da região sul, Brasil (Chiroptera, Phyllostomidae, Vespertilionidae, Molossidae). Curitiba: Universidade Federal do Paraná. 115 p. Tese de doutorado.

PINHEIRO, EC., TADDEI, VA., MIGLIORINI, RH., KETTELHUT, IC., 2006. Effect of fasting on carbohydrate metabolism in frugivorous bats (Artibeus lituratus and Artibeus jamaicensis). Comparative Biochemistry and Physiology Part B: Biochemistry and Molecular Biology, vol. 143 , p. $279-284$.

PIRLOT, P., 1967. Periodicite de la reproduction chez les chiropteres neotropicaux. Mammalia, vol. 31, p. 361-366.

PROTZEK, AOP., RAFACHO, A., VISCELLI, BA., BOSQUEIRO, JR, CAPPELLI, AP., PAULA, FMM., BOSCHERO, AC., PINHEIRO, EC., 2010. Insulin and glucose sensitivity, insulin secretion and $\beta$-cell distribution in endocrine pancreas of the fruit bat Artibeus lituratus. Comparative Biochemistry and Physiology Part A: Molecular \& Integrative Physiology, vol. 157, p. 142-148.

SARTORI, DRS., MIGLIORINI, RH., VEIGA, JA., MOURA, JL., KETTELHUT, IC., 1995. Metabolic adaptations induced by long-term fasting in quails. Comparative Biochemistry and Physiology Part A: Physiology, vol. 111, p. 487-493.

SILVA, SM., MIGLIORINI, RH., 1990. Effects of starvation and refeeding on energy-linked metabolic process in the turtle (Phynops hilarii). Comparative Biochemistry and Physiology Part A: Physiology, vol. 96, p. 415-419.

SRIVASTAVA, RK., KRISHNA, A., 2007. Adiposity associated rise in leptin impairs ovarian activity during winter dormancy in Vespertilionid bat, Scotophilus heathi. Reproduction, vol. 133, p. 165-176.

SRIVASTAVA, RK., KRISHNA, A., 2008. Seasonal adiposity, correlative changes in metabolic factors and unique reproductive activity in a vespertilionid bat, Scotophilus heathi. Journal of Experimental Zoology Part A: Ecological Genetics and Physiology, vol. 309, p. 94-110.

SPEAKMAN, JR., ROWLAND, A., 1999. Preparing for inactivity how insectivorous bats deposit a fat store for hibernation. Proceedings of the Nutrition Society, vol. 58, no. 1, p. 123-131.

TAPPY, L., 1995. Regulation of hepatic glucose production in healthy subjects and patients with non-insulin-dependent diabetes mellitus. Diabete \& Metabolisme, vol. 21, p. 233-240.

TAPPY, L., 2004. Glucagon et glucorégulation. Annales d'Endocrinologie, vol. 65, p. 77-79.

TURBILL, C., KÖRTNER, G., GEISER, F., 2003. Natural use of heterothermy by a small, tree-roosting bat during summer. Physiological and Biochemical Zoology, vol. 76, p. 868-876.

VICENTE, EC., EMILIANI, VC., OLIVEIRA, LF., FAVERO, S., 2006. Análise morfométrica e anatômica do útero em famílias de quirópteros (Mammalia) que ocorrem no Brasil. Ensaios e Ciência, vol. 10, no. 1, p. 63-73.

VOIGT, CC., SÖRGEL, K., DECHMANN, DK., 2010. Refueling while flying: foraging bats combust food rapidly and directly to power flight. Ecology, vol. 91, p. 29082917.

WOJCIECHOWSKI, MS., JEFIMOW, M., TÊGOWSKA, M., 2007. Environmental conditions, rather than season, determine torpor use and temperature selection in large mouse-eared bats (Myotis myotis). Comparative Biochemistry and Physiology Part A: Molecular \& Integrative Physiology, vol. 147, p. 828-840. 